\title{
Marc Mulholland How Revolutionary Was the "Irish Revolution"?
}

"MY LORDS, FOR TEN YEARS . . . it is no exaggeration, it is the literal truth to say that there has been going on in Ireland a great revolution-social partly, political partly." So said Sir Charles Russell QC in $\mathrm{I} 889$. He was addressing the special commission sitting in judgment on the Land War and the rise of the radical Parnellite nationalist party since I879. We are now more likely, however, to think of the ten years between I9I2 and I923 as the "Irish Revolution." This way of thinking is relatively new. It is true that the language of revolution can be found in Irish history, particularly in the ambiguity of the militant separatist tradition. Until reorganization in 1873 there was no formal certainty whether the initials IRB indicated that this Irish brotherhood was "revolutionary" or "republican."2 "Revolutionary" was generally understood to signal a commitment to illegality, and in this regard the distance from "constitutional" nationalism could easily shrink, as episodes such as the I879-82 Land War had shown. ${ }^{3}$ But while we can find self-identifying "revolutionaries" in modern Ireland, and revolutionism elided with militancy, can we claim as a revolution the period in which the independent Irish state was founded and Northern Ireland carved out?

A couple of instant histories at the time did refer to the period as a revolution. Alison Phillips defined the collapse of British rule in most of Ireland as the local expression of an ongoing international "revolution," a generalized crisis of stable hierarchy and empires. For this reason he called his book The Revolution in Ireland rather than The

I. Sir Charles Russell, The Parnell Commission:The Opening Speech for the Defence (London: Macmillan, I889), 4.

2. P. S. O'Hegarty, A History of Ireland under the Union, I80I-I922 (London: Methuen, I952), 4I4-I5.

3. T. W. Moody, Davitt and the Irish Revolution, I846-82 (Oxford: Clarendon Press, 1982), 26-27. 
Irish Revolution. ${ }^{4}$ From a nationalist perspective, we find a similarly ambiguous categorization of Ireland's experience as "revolution." William O'Brien, in his book The Irish Revolution and How It Came About, described the process in rather unrevolutionary terms: at once a militant backlash against home rule, and as its constitutional consummation. $^{5}$

These descriptors of "revolution" did not stick in the years after Irish independence and partition. In general, no fixed term came to describe as a totality the series of episodes including the third Home Rule bill and "Ulster Crisis" of I9I2-I4, the I9I3 Lock Out, the I9I6 Easter Rising, the 1919-2 I Anglo-Irish War, the 1920-22 UlsterTroubles, and the 1922-23 Irish Civil War. For a society that still remembered these episodes with all too sharp clarity, and not yet concerned with how to collectively label them in a "decade of centenaries," these were intertwined paternosters. When a blanket term was felt to be required, that old term "Irish Troubles" was often rolled out. ${ }^{6}$ Padraic Colum, in his 1959 celebration of Arthur Griffith, the founder of moderate Sinn Féin, argued that the "Irish Revolution affords . . . an admirable and somewhat neglected case history of a nationalist revolution in our modern Western world." many willing to take up the term "nationalist revolution," however. In Cold War Ireland the milieu of conservative Fine Gael nationalism was unlikely to enthuse about revolution of any sort. The term used around the fiftieth anniversary celebrations of 1916, stoutly ignored by Ulster Unionists, was “The Irish Uprising” or, more neutrally, in I969, "The Conflict."8

4. W. Alison Phillips, The Revolution in Ireland, 1906-1923 (London: Longmans, I926), xi.

5. William O'Brien, The Irish Revolution and How It Came About (Dublin: Phoenix, 1923), 43.

6. Edgar Holt, Protest in Arms: The Irish Troubles, 1916-1923 (London: Putnam, I96I).

7. Padraic Colum, Ourselves Alone! The Story of Arthur Griffith and the Origin of the Irish Free State (New York: Crown Publishers, I959), x.

8. Goddard Lieberson, The Irish Uprising, I9I6-I922 (New York: Macmillan, I966); Peadar Livingstone, The Fermanagh Story: A Documented History of the County Fermanagh from the Earliest Times to the Present Day (Enniskillen: Cumann Seanchais Chlochair, 1969), chapter 24. "The Irish revolution" was used to describe the period I9I6 to I92 I in T. M. Donovan, A Popular History of East Kerry (Dublin: Talbot Press, I93I), I04-24. 
Revolution as a descriptor appeared at the end of the I960s in the wave of national liberation struggles in the global south. For Oliver MacDonagh, the revolutionary delusions of "half-crazed millenarians" had to be yoked to the sober constitutionalism of Arthur Griffith's Sinn Féin to win independence. ${ }^{9}$ F. S. Lyons likewise depicted the merging of a separatist underground with moderates to achieve at least a "thwarted revolution." 10 In I97I C. Desmond Greaves used the term "Irish revolution" in his biography of the leftist anti-Treaty leader Liam Mellowes. Greaves characterized the period as an incomplete "national revolution." The political implication of this in the context of the Northern Ireland Troubles, escalating as he wrote, was obvious. ${ }^{11}$ George Dangerfield in his 1976 study of the period The Damnable Question also spoke of the "unfinished revolution" as a missed opportunity for an independent united Ireland. ${ }^{12}$ More influential was J.G.A. Pocock's contribution in 1975, also influenced by the Northern crisis, which identified "the Irish revolution of I9II-22" as a regrettable disruption of Greater British history by a compulsively romantic nationalism on Eastern European or Third Worldist lines. This Irish revolution was "the first terrorist war of modern times." ${ }^{13}$ Tom Garvin took up and developed Pocock's suggestion that Ireland's separatism was a subset of those revolutions of maladjustment allegedly driven by socially declining classes marginalized and upset by modernization. Garvin identified a "long political revolution" lasting from I858 to I928, the contemporaneous Northern Ireland Troubles being excluded from this expansive schema by rather strained definitional means. ${ }^{14}$

In the late I980s there was certainly no agreement that a revolution had taken place in the era of independence and partition,

9. Oliver MacDonagh, Ireland (Englewood Cliffs, NJ: Prentice-Hall I968), 75, 77 .

I0. F.S.L. Lyons, Ireland since the Famine (London: Weidenfeld and Nicolson, I97I, I973), 505 and passim.

II. C. Desmond Greaves, Liam Mellows and the Irish Revolution (London: Lawrence and Wishart, 197I).

I2. George Dangerfield, The Damnable Question: A Study in Anglo-Irish Relations (London: Constable, 1976), 344-48.

I3. J.G.A. Pocock, "British History: A Plea for a New Subject," Fournal of Modern History 47 (Dec. 1975): 60I-28, 606.

I4. Tom Garvin, "The Anatomy of a Nationalist Revolution: Ireland, I858I928," Comparative Studies in Society and History 28:3 (July I986): 468-50I, 469. 
though, as David Fitzpatrick now admitted, it had become the "most tantalising question in Ireland's recent history." ${ }^{15}$ This was a period of enthusiastic historical revisionism blackguarding revolution as such and Irish historians, much disgusted by the dreary conflict in the North, were no doubt keen to get in on the act. When applying the concept of revolution to Ireland, nonetheless, the major tone was one of ambiguity and doubt. The preface to a I 988 essay collection on "Revolution in Ireland," edited by George Boyce, could not quite take the concept seriously. Ireland between I916 and 1923, Boyce remarked breezily, was revolutionary in so far as it was characterized by "skulduggery." This was a revolution, if at all, only on the Greek model. Once the wheel had turned, and the Treaty signed, Ireland was much as it had been. ${ }^{16}$

In the same year, R. F. Foster published his agenda-setting Modern Ireland. This included a chapter entitled "War and Revolution" and finally the concept slipped berth. But Foster was more careful than his successors. The "war" in his couplet referred not to the war of independence, but the Great War. The "revolution," brought about chiefly by the shock of the European cataclysm, was the electoral triumph of Sinn Féin over the constitutional Irish Parliamentary Party (IPP). This was far from a claim of an Irish revolution tout court. Foster, indeed, stressed its equivocal scope: "Who ... had the revolution been against . . ? What was being fought for . . . ?"17 In subsequent historiography this questioning tone would fade.

Over the next twenty years, imperceptibly but definitely, the early twentieth-century "Irish Troubles" became accepted as an indubitable revolution. ${ }^{18}$ Revolution had come back in fashion both with centrists, who could look with some satisfaction of the anticommunist and "colour" revolutions of Eastern Europe, and the left-liberal enthusiasts for intersectional identities, who increasingly redefined revolution as rather festive anticipations of contemporary cultural

I5. David Fitzpatrick, ed., Revolution? Ireland, I9I7-I923 (Dublin: Trinity History Workshop, 1990), preface.

I6. D. G. Boyce, ed., The Revolution in Ireland (Basingstoke, UK: Macmillan, I988), I-3.

I7. R. F. Foster, Modern Ireland, I600-1972 (London: Allen Lane, I988), 492-93.

I8. Marie Coleman's 20I4 textbook on the I9I6-23 period was simply called The Irish Revolution, 1916-I923 (Abingdon and London: Routledge, 2014). Four Courts in Dublin is publishing county monograph studies in its Irish Revolution, 1912-23 series. 
ideals. The decade of centenary anniversaries in Ireland saw a torrent of books and articles speaking unproblematically of an "Irish revolution." ${ }^{\prime 19}$ Oddly, this almost insensible acceptance of the term has never been accompanied by any sustained discussion of scholarly paradigms of revolution and how it might apply to Ireland. In 2002, however, Peter Hart in a short essay did indicate an ideal-type. From Charles Tilly he borrowed the definition of a revolution as an "open division of sovereignty" in which "two distinct blocs" make incompatible claims for control of the state, dividing the population. This definition was rather obviously influenced by the "dual power" of the Russian Revolution, and can apply just as well to the rebellion of a satrapy against an overlord, as if the disorder which followed the death of any Persian "king of kings" was a revolution. Hart therefore added an "equal emphasis on the revolutionary struggle or process." For Hart, this meant primarily armed violence and ethnic conflict. ${ }^{20}$

Not everyone, perhaps, was entirely convinced..$^{21}$ Charles Townshend, writing in the same volume as Hart, was rather doubtful that events in Ireland amounted to a revolution, but he was prepared to go with the flow, because "it remains plainly true that the events of the war and postwar period were felt by their proponents ... to be a revolution. In this sense, at least, the categories of political science are irrelevant to lived experience."22

19. A partial dissent is provided by Aidan Beatty, who seeks to apply Gramsci's notion of "passive revolution." As Gramsci had meant by this domination of the bourgeois revolution by a monarchical and landed elite, its appropriateness for Ireland seems doubtful. Aidan Beatty, "An Irish Revolution without a Revolution," fournal of World-Systems Research 22:I (2016), 54-76.

20. Peter Hart, "Definition: Defining the Irish Revolution," in The Irish Revolution, 1913-1923, ed. Joost Augusteijn (Basingstoke, UK: Macmillan, 2002), I7-I8.

21. In I999 John Regan noted a "growing consensus among historians that the changes that occurred in Ireland between I9I2 and 1922 constituted a revolution," but a consensus still vitiated by "a degree of discomforture." John M. Regan, The Irish Counter-Revolution, 1921-36: Treatyite Politics and Settlement in Independent Ireland (Dublin: Gill and Macmillan, 1999), xiii.

22. Charles Townshend, "Historiography: Telling the Irish Revolution," in Augusteijn, The Irish Revolution, 8. Eugenio Biagini accords the Irish experience its status as a revolution because it was pushed along by a typically small "revolutionary elite." This surely begs the question, and is anyway of doubtful applicability. The I9I6 rebellion, carried out by a small minority, was hardly of itself a revolution. The sweeping electoral success of Sinn Féin in I9I8 belies a tiny minority. That a fairly small network ran the Irish Dáil Government and war effort hardly distinguishes it 


\section{Was It Seen as a Revolution?}

Did the generation of $1913-23$ actually believe that they had lived through a revolution? This is not at all clear. A search of the online British Library Newspaper Archive finds 858 uses of the term "Irish revolution" for the period I879 to I898, many referring to the period of the Land War. For the same span of years after I9I6, up to I935, there are only 237 hits, most of these expatiating on various alleged plots rather than seeking to characterize the Irish independence and partition period as a whole. ${ }^{23}$ The equivalent figures for the online Irish Newspaper Archive, in contrast, are I02 hits for "Irish revolution" in the $1879-98$ period compared to 214 for the years I9I6-35. For the I9I6 to I935 period, however, the terms "Irish Troubles" (458), "Tan War" (833) and "Anglo-Irish War" (2542) easily predominate. ${ }^{24}$

In the I,773 witness statements and 334 sets of contemporary documents collected by the Bureau of Military History to track the "history of the movement for independence" from I9I3 to I92I, the term "revolution" brings up only 65 hits, disproportionately from veterans of the small Irish Citizen Army. Even these labor-movement veterans usually talked about revolution in general rather than of an Irish revolution. ${ }^{25}$ Some witnesses were citing historical events such as the French Revolution and the Glorious Revolution. When "revolution" or its cognates were applied to the period I9I3 to I92I, it was usually to indicate the I9I6 Rising or the calculated intervention by the small IRB cadre rather than the much larger scale struggle of the war of independence. Patrick McCartan, a member of the Supreme Council of the IRB, only used "revolution" as a synonym for a "ris-

from nonrevolutionary governments and war efforts. Eugenio Biagini, "Review Article: The Irish Revolution, I916-23," English Historical Review I21:548 (Feb. 2016), I22-32.

23. For the latter, the second hit is "Not an Irish Revolution," an article in the Yorkshire Evening Post, I7 Nov. I92I. This article quoted an unnamed southern unionist preferring his theory of "a German-Jew-Bolshevik attack on the British Empire."

24. Despite the title of Maurice Walsh's study, The Nerws from Ireland: Foreign Correspondents and the Irish Revolution (London: I. B. Tauris, 20II), there are no citations therein of any foreign correspondents actually using the term to describe events in Ireland.

25. William O'Brien Witness Statement (hereafter cited as WS) I766 (Bureau of Military History Collection [hereafter cited as BMH], Military Archives of Ireland, Dublin [hereafter cited as MA]). 
ing" or insurrection, unless he was talking about Russia. ${ }^{26}$ Insofar as revolution was applied to the transformation in Ireland, it was ambiguous. Kevin O'Shiel talked of Ireland undergoing a "psychological revolution." 27 For IRA volunteers straining at the leash, it justified aggressive military actions in advance of public opinion. Seamus Robinson explained, "it was my conviction that, during revolution periods, if the thing be morally right in itself and at the same time urgent and necessary, it would be legitimised subsequently." 28 Overall, however, it is clear that veterans were not minded to understand the own experience as primarily revolutionary. Kitty O'Doherty, Cumann na mBan, explicitly denied the label as a British-inspired delegitimisation. ${ }^{29}$ There is something to this. Major-General Charles Foukes, the director of British propaganda in Ireland from I92I, instructed his subordinates to depict the IRA as "a gang of terrorists, . . a murder gang: compare them to Lenin and Trotsky." 30

Nonetheless, even if people at the time did not think in terms of an Irish revolution unless they were making quite specific or polemical points, this does not prevent the historian from retrospectively applying the term. Though scholars sometimes speak of its "natural history," revolution of course is not an objective thing but an interpretation, and like most interpretations it does not have a single agreed definition. Nonetheless, revolution is typically seen as a process. Scholarship generalizing the concept has been divided into "generations." The first, provoked by the red wave in Europe at the end of the Great War, attempted to develop a model of typical revolutionary processes, from breakdown through radicalization to reaction or consolidation. A second generation, against the backdrop of the Cold War in the Global South, proposed structural explanations for revolution as resulting from blocked societal modernization. The third generation, rising as industrial class politics declined in the

26. Patrick McCartan WS 766 (BMH, MA).

27. Kevin O'Shiel WS $\mathrm{I} 770(\mathrm{BMH}, \mathrm{MA})$. This is clearly what Pearse had in mind in his oft-cited and over-interpreted article "The Coming Revolution," $A n$ Claidheamh Soluis, 8 Nov. I9I3, reprinted in Pádraic H. Pearse, Political Writings and Speeches (Dublin: Talbot Press, 1966), 94.

28. Seumas Robinson WS I72I (BMH, MA), 4.

29. Kitty O'Doherty WS 355 (BMH, MA).

30. William Sheehan, A Hard Local War: The British Army and the Guerrilla War in Cork, 1919-I92I (Stroud: History Press, 2011), I09. 
I970 and I980s, emphasized the abrasive interaction of modernizing states and peasant societies. The fourth generation, from the I990s onward, drew upon postmodern contexts of contingencies, language and mobilizing illusions. From all of this, certain midrange theories of considerable power have emerged, even if meta-analyses remain elusive. Drawing upon the literature, we can map out an ideal-type revolutionary process into elements as follows:

I. State breakdown under pressure of international events

2. The eruption of the masses into the political arena

3. Class conflict

4. Mutual radicalization of revolution and reaction

5. Moderation to radicalization in leadership

6. Coercion to create constituencies

7. Purging of the state apparatus

8. Significant transformation in the mode of production, or at least property allocation

9. The establishment of a new dominant ideology

How do these apply to the Irish case?

\section{State Breakdown under Pressure of International Events}

The idea of revolution as the domestic reflux of international pressure is well-established in the historiography. ${ }^{31}$ There is no doubt that international events impacted upon the United Kingdom in the period I9I3 to 1923, but it is difficult to argue that it endured an existential international crisis. After all, it successfully waged war against the Central Powers. It is certainly the case that the combined impact of the Russian Revolution and the American entry into war created a set of circumstances that made Britain's refusal to concede selfdetermination to Ireland somewhat embarrassing. There was cause for optimism among Irish separatists. As Seán Ó Faoláin wrote in the late i930s,

The general atmosphere of international politics then was far different from what it is now. ... Versailles was supposed to be settling for ever all national injustices, especially those of the small nations.

3I. Theda Skocpol, States and Social Revolutions: A Comparative Analysis of France, Russia, and China (Cambridge: Cambridge University Press, 1979). 
There was a tremendous feeling of optimism and general philanthropy abroad. . . . It was therefore not only natural for a country like Ireland to want something from that, but it was by no means beyond the bounds of practical politics. ${ }^{32}$

But it would be entirely wrong to say that Britain was forced by this general atmosphere into a collapse of its state capacity. And as President Wilson made clear, for all the high principles of selfdetermination enunciated by the victors in I9I8, the Paris Peace Conference was only meant to facilitate self-determination for those "territories which belonged to the defeated empires." 33 Britain was a victorious empire and while it suffered from a crisis of morale among its domestically recruited forces in nationalist Ireland, the ease with which the Black and Tans and Auxiliaries were recruited in Britain show that its coercive capacity remained robust.

\section{The Eruption of the Masses into the Political Arena}

Nothing is perhaps more associated with revolution than the sudden salience of the domineering masses assembled in rebellious crowds and dictating to fearful government. ${ }^{34}$ There was considerable popular mobilization across Ireland in the period I9I3-23 but we need to remember that this was by no means new in Irish history. The Irish demos had been markedly active in mass political organization, on and off, since the I820s at least. Peter Gibbon points out that in the forty years or so since around I880, "almost the entire population underwent regular political mobilization." 35 Even by British standards, the "popular platform" in Ireland had been pervasive, at varying but frequently high levels, since the monster meetings of Daniel O’Connell.

32. Seán Ó Faoláin, DeValera: A New Biography (Harmondsworth, UK: Penguin, I939), 64-65.

33. Jérôme aan De Wiel, The Irish Factor, I899-1919: Ireland's Strategic and Diplomatic Importance for Foreign Powers (Dublin: Irish Academic Press, 2008), 389.

34. Stefan Jonsson, A Brief History of the Masses: Three Revolutions (New York: Columbia University Press, 2008).

35. Peter Gibbon, The Origins of Ulster Unionism: The Formation of Popular Protestant Politics and Ideology in Nineteenth-Century Ireland (Manchester: Manchester University Press, 1975), 3. 
It is difficult to identify a qualitative leap forward in popular mobilization for the period I9I3-23. We can find little or no direct pressure on the seats of government, as is normal in a revolution. During the I9I6 Rising there was no general strike or popular émeute, nor any attempt to call for one. "If only the people had come out, even armed only with knives and forks," De Valera is reputed to have lamented. ${ }^{36}$ But they did not. Connor Kostick has argued that it was the working class that struck the "main blows" against the British administration during the war of independence. ${ }^{37}$ But those ordinary workers in Kilkenny, interviewed by Marylin Silverman in the succeeding generation, saw their ancestors as objects in the war, not subjects. ${ }^{38}$ As Hart has noted, the war of independence "was waged largely by small bands of gunmen." In a sense, he continues, "the revolution came down to a confrontation between these groups." ${ }^{39}$ But this detracts from rather than characterizes a revolutionary process.

Though military volunteering was the cutting edge of separatist militancy in the period, there were of course mass demonstrations. But these looked distinctly unrevolutionary. The characteristic public manifestation was the pacific vigil and rosary in solidarity with combatant prisoners. This was the overriding impression broadcast internationally and long remembered as emblematic of the struggle in Ireland. ${ }^{40}$ It seems significant that the Bloody Sunday of the war of independence was not inflicted upon a protesting or riotous crowd, but against peaceable football spectators, and was followed on the same day by clinical assassinations carried out by Michael Collins's elite body of gunmen, the "squad."

36. Walter Starkie, Scholars and Gypsies: An Autobiography (Berkeley and Los Angeles: University of California Press, I963), I5I.

37. Conor Kostick, Revolution in Ireland: Popular Militancy, 19I7-I923 (London: Pluto Press, I996), 2.

38. Marilyn Silverman, An Irish Working Class: Explorations in Political Economy and Hegemony, I800-1950 (Toronto: University of Toronto Press, 200I), 252-53.

39. Peter Hart, The I.R.A. and Its Enemies:Violence and Community in Cork, I9I61923 (Oxford: Clarendon Press, I999), I8. 66.

40. Camille Bourniquel, Ireland, trans. John Fisher (London:Vista Books, I960), 


\section{Class Conflict}

Acute class conflict is inseparable from most definitions of revolution. ${ }^{41}$ Class conflict had long been an important aspect of nationalism and antinationalism in Ireland, but it is difficult to see the "Irish revolution" as a rupture in the social structuration of Irish society. Class did have a role in the struggle for national independence, for outside Ulster it had long crystallized as a contest between the Catholic demos and the landed and bourgeois unionist elites. Landlordism, the social core of southern unionism, was already fast collapsing into the grave. Home rule itself had been anticipated as a final breaking of the political power of the landed elite. ${ }^{42}$ Rural class tensions certainly survived. M. Philips Price, in a visit to the west of Ireland in I909, was struck by the resentful animosity he found in the landlords' country homes and how they spoke of the peasantry "as if they were animals." ${ }^{33}$ Unsurprisingly, echoes of the rural class conflict were evident during the war of independence. Lionel Fleming recalled an illustrative anecdote, told to him by his unionist landowning father, of an "inexcusable indiscretion at a tea party he attended":

A British officer revealed casually that a local landowner had done him a good turn by supplying him with certain information. When one of the company signalled him to stop talking, the officer was quite indignant. "Why," he said, "we're all loyal here, aren't we?" So they were, except of course for the parlour maid, and within a day or so that landowner was forced out of the country. ${ }^{44}$

The unionists in southern Ireland learned now, if they had not already realized, that the loyalty of the lower orders was not to be relied upon.

Crucially, however, there was no Land War to accompany the Anglo-Irish War. Since the 1903 Wyndham Land Purchase Act, which began the process of transferring land from lords to farmers, the rural class struggle had lost much of its vehemence. As Philip Bull has pointed out, this meant that the constitutional-nationalist movement

4I. Ted Gurr, Why Men Rebel? (Princeton, NJ: Princeton University Press, 1971).

42. Arthur Cleary, cited in Senia Pašeta, Before the Revolution: Nationalism, Social Change and Ireland's Catholic Elite, I879-19I4 (Cork: Cork University Press, I999), 47.

43. M. Philips Price, My Three Revolutions: Russia, Germany, and Britain, I9I71969 (London: Allen and Unwin, I969), 221.

44. Lionel Fleming, Head or Harp (London: Barrie and Rockliff, I965), 6I. 
suffered as its base shrunk. Increasingly, it became "a party of class and sectional interests." ${ }^{45}$ We can therefore see the rise of Sinn Féin as a reaction to outmoded class conflict rather than an expression of it. Separatism was not a class movement. Republicans were certainly prepared to instrumentalize land agitation to their own end, but they held aloof from its passions. Michael Brennan, the principal IRA officer in County Clare, remarked that he "hadn't the slightest interest in the land agitation" as such, "but I had every interest in using it as a means to an end, ... to get those fellows into the Volunteers ... and up to that they were just an unorganised mob." ${ }^{\prime 6}$

There was considerable class conflict between capitalist and wage earner, with an early climacteric in the Dublin Lock Out of 1913. But the wages movement did not power the rise of separatism. As a clerical observer of the time noted, "There is a danger of distorting the origins of the Rising by beginning with the Labour troubles of I9I3. ... The influence of Labour is far below another factor rarely alluded to- the education of thousands and thousands of plain Irish boys by the Irish Christian Brothers. I hold strongly that it was the atmosphere of their schools and training of the Brothers that provided the foundation, the materials and, to a very large extent, the builders of the Irish separatist movement that culminated in 1916." ${ }^{\prime 7}$ This has been substantially confirmed by subsequent scholarship. ${ }^{48}$

The organized working class was grievously split between North and South. Aware of its weakness, Labour did not stand against Sinn Féin in the 1918 election in nationalist constituencies. Both sides were happy for labor to wait. The rise of a militant proletarian movement, evident in the mass activism of the Irish Transport and General Workers Union (but not the Irish Trade Union Congress and Labour Party), took place in parallel with separatist nationalism, and in many important aspects was ancillary to it. It never looked like replacing it or even defining its agenda.

45. Philip Bull, Land, Politics, and Nationalism: A Study of the Irish Land Question (Dublin: Gill and Macmillan, I996), I7I.

46. Michael Hopkinson, Green against Green:The Irish CivilWar (Dublin: Gill and Macmilla, I988), 45.

47. M. J. Curran WS 687 (BMH, MA), 5.

48. Peter Hart, The I.R.A. at War, 1916-1923 (Oxford: Oxford University Press, 2003), 56-57. 
It is certainly true that Sinn Féin support, compared to that of the home-rule movement it displaced, was somewhat more plebeian, and it was certainly strong among the laboring and small farmer class. But the divide between nationalists old and new was marked much more by age than by wealth, status, or mode of work. By the end of I9I8 Sinn Féin easily engrossed the majority of pan-classnationalist Ireland. ${ }^{49}$ Classless Sinn Féin looked quite different to the constitutional-nationalist movement, with its dubious roots in rural class warfare and unromantic trunk of materialistic farmers and merchants. By I9I8 the urbane salons "were all full of rebels," George O'Brien remembered, "rebels with genteel outlooks and upper-class accents." ${ }^{50}$ The hard men of the IRA who emerged in I9I9 were rebels in much greater earnest, it is true. But these country lads "with neither financial nor social standing" still looked for commandants "whose qualifications would provide the necessary prestige." ${ }^{51}$ Class hierarchies were barely challenged.

\section{Mutual Radicalization of Revolution and Reaction}

Revolutions do not stand alone but develop from fear of counterrevolution. The whip of reaction drives reform into revolution. ${ }^{52}$ There was overall little dynamic of reaction radicalizing revolution in Ireland. Nationalists did not really fear unionist reaction. Indeed, separatists were surprisingly blasé about it; if anything, unionism was more of a backhanded inspiration. The Irish Volunteers were established in emulation of the Ulster Volunteer Force: "The North Began." Ulster's defiance of the Liberal government's enactment of home rule in I9I2-I4, supported by British Conservatives, struck many at the time as an ironic commendation of subversion: "If ever

49. Michael Laffan, The Resurrection of Ireland: The Sinn Féin Party, I9I6-19I8 (Cambridge: Cambridge University Press, I999), I88, I90-92.

50. James Meenan, George O'Brien: A Biographical Memoir (Dublin: Gill and Macmillan, I980), 76.

5I. Dan Breen, My Fight for Irish Freedom (1924; Dublin: Anvil Books, I98I), 2 I. See also Tom Garvin, Nationalist Revolutionaries in Ireland, I853-I928 (Oxford: Clarendon Press, 1987), 50-53.

52. Marc Mulholland, "Revolution and the Whip of Reaction: Technicians of Power and the Dialectic of Radicalisation," Fournal of Historical Sociology 30:2 (June 2017): 369-402. 
a bloody revolution breaks out in this country," wrote the leftist Gerald Gould in I920, "a large share of the responsibility will have to be borne by Mr. Bonar Law and other Tory leaders who made incendiary speeches on the Ulster theme." 53 British military authorities supported Ulster unionist defiance of Parliament, as shown by the I9I4 Curragh Mutiny, but with that doublethink characteristic of the authoritarian mindset nonetheless blamed the Liberals for permitting a bad example. General John Maxwell, arriving in Dublin to put down the I9I6 rising, scribbled frustrated notes: "It is the government as a whole that are to blame, ever since they winked at Ulster breaking the law they have been in difficulties and have hoped and hoped that something would turn up, get them out without their doing anything themselves-"wait and see" —-well we have waited and now we see the result, viz. rebellion and loss of life." ${ }^{54}$

From around I9I4 the focus quickly moved from Irish loyalism as a reaction to Irish nationalism to Ulster unionism as a separation from nationalist Ireland in the messy form of partition. Southern unionism, with its strong connections to the British political elite, was actively reactionary in the 1916 Lloyd George negotiations, when the British government attempted to expedite a form of home rule in the aftermath of the Rising. As Patrick Buckland demonstrates, the Easter Rising "caused a southern unionist reaction which helped thwart a settlement in July 1916." ${ }^{55}$ But this was the last hurrah of southern unionism. By the time it arrived at the 1917-I8 Irish Convention, it had effectively surrendered to even the most radical form of home rule (too late). On behalf of southern unionism, Lord Middleton proposed an Irish Parliament with control of internal taxation, excise duties, administration, judicature, and police. The Ulster Unionists were dumbfounded: "They want to capitulate and make terms with

53. Gerald Gould, The Coming Revolution in Great Britain (London: Collins, I920), 75. See also J. A. Hobson, Traffic in Treason (London: T. F. Unwin, I9I4). According to Fanning, the Ulster unionists and the British Conservative Party embraced "a policy of revolution without parallel in modern British history." Unionists in fact saw themselves as counterrevolutionary. Ronan Fanning, Fatal Path: British Government and the Irish Revolution, 1910-1922 (London: Faber and Faber, 2013), 52.

54. R. F. Foster, Vivid Faces: The Revolutionary Generation, I890-1923 (London: Allen Lane, 20I4), 217.

55. Patrick Buckland, Irish Unionism, I: The Anglo-Irish and the New Ireland, I8851922 (Dublin: Gill and Macmillan, I972), 5 I. 
the enemy lest a worse thing befall them." ${ }^{56}$ All-Ireland unionism, formidable for so long, had collapsed and could not by its opposition radicalize Irish nationalism into cumulative radicalism.

Southern unionism had little fight left in it. Its leading stratum, the landed elite, had been gutted by the World War. Douglas Hyde, though himself a nationalist, felt the pain of this class. "Nearly everyone I know in the army has been killed," he wrote in I9I5. "All the gentry has suffered. Noblesse oblige. They have behaved magnificently." ${ }^{57}$ So they had, but it was a valedictory blood sacrifice. The social basis of reaction, demoralized and defeated, collapsed. By I92 I, R. B. McDowell writes, southern unionists "had scarcely a vestige of political power." ${ }^{58}$ In different circumstances, they might have received artificial resuscitation. Had the Truce had broken down, the British intended to form loyalists as a civic guard to help in "the reconquest of the country." ${ }^{59} \mathrm{We}$ may be glad that this did not come to pass. Ascendancy power ended in most of Ireland with the Treaty, though a certain gentry unionism continued in Northern Ireland down to Prime Minister James Chichester-Clark. ${ }^{60}$ For the 19I2-23 period, there was no sustained dialectic of reaction and revolution outpacing each other.

\section{Moderation to Radicalization in Leadership}

Crane Brinton famously argued that the life cycle of revolution sees moderates displaced by increasingly fanatical radicals. ${ }^{61}$ Katharine Tynan, a literary supporter of the home rule leader John Redmond, said of him in 1924 that "he would have made Ireland a

56. An Ulster unionist, quoted in R. B. McDowell, The Irish Convention, I9I7-I8 (London: Routledge, 1970), I30.

57. Janey Egleson Dunleavy and Gareth W. Dunleavy, Douglas Hyde: A Maker of Modern Ireland (Berkeley: University of California Press, I99I), 325.

58. McDowell, Irish Convention, I30.

59. Peter Hart, "The Protestant Experience of Revolution in Modern Ireland," in Unionism in Modern Ireland: New Perspectives on Politics and Culture, ed. Richard English and Graham Walker (Dublin: Gill and Macmillan, 1996), 90.

60. Michael McConville, Ascendancy to Oblivion: The Story of the Anglo-Irish (London: Quartet Books, 1986), 262.

6I. Crane Brinton, The Anatomy of Revolution, rev. ed. (New York:Vintage Books, 1965). 
little England." ${ }^{2}$ She meant it as a compliment, but Redmond's separatist rivals and successors feared as much. Nonetheless, while there is no doubting a marked chromatography of nationalism in Ireland in this period, we need to be careful not to overstate the polarization between republicanism and constitutionalism. Augustine Birrell, chief secretary of Ireland, in the aftermath of the I9I6 Rising remarked perspicaciously on the base-level continuity of Irish nationalism: "The spirit of what is today called Sinn Féinism is mainly composed of old hatreds and distrust of the British connection, always noticeable in all classes, and in all places, varying in degree, and finding different ways of expression, but always there as the background of Irish politics and character." ${ }^{63}$ The British political elites, indeed, were quite well aware (and only mildly concerned) that they held Ireland against the will of its majority population. Ireland was unique "among all the portions of the empire," Gladstone wrote in I886: "All the rest are held together by freewill; she alone is under the bond of force." 64

Pat Walsh has argued that in the period ca. 1908 to I9I2 elements of the IPP leadership, and in particular John Redmond, moved from a tactical and rather insincere promotion of self-government within the British Empire, along the lines of South Africa after the Boer War, to a genuine and internalized commitment to liberal imperialism. ${ }^{65}$ There may be something to this. The prospect of Westminster becoming a genuine imperial parliament equidistant from associated nation-states, somewhat analogous to the parliament of today's European Union, had a certain appeal. However, if popular enthusiasm for empire was rather tepid even in Great Britain, as Bernard Porter has convincingly argued, it was positively tenuous-one might say vir-

62. Katharine Tynan, Memories (London: Nash and Grayson, I924), 68.

63. "Report of the Royal Commission on the Rebellion in Ireland, 1916," in The Irish Uprising, 1914-I92I: Papers from the British Parliamentary Archive (London: Stationery Office, 2000), 83.

64. W. E. Gladstone, Special Aspects of the Irish Question (London: John Murray, I892), I8.

65. Pat Walsh, The Rise and Fall of Imperial Ireland: Redmondism in the Context of Britain's Conquest of South Africa and Its Great War on Germany, I899-I9I6 (Belfast: Athol, 2003), I47-48, and passim. 
tually nonexistent-in nationalist Ireland. ${ }^{66}$ For those few who paid attention, the British Empire was a fact of life that was at once irksome, unavoidable, and in some respects idealistic. Redmond at any rate refused to make the Irish national demand for home rule conditional on any federalizing reform of the United Kingdom, still less the empire. ${ }^{67}$ Despite the fantasies of Cecil Rhodes, Irish nationalism could never be a convincing vector for British imperialism. On the other side of the nationalist spectrum, a purely instrumental attitude toward Britain's empire survived Redmond's debacle. De Valera at the time of the treaty debates was quite prepared to link Ireland with the British Empire in the form of "external association," while balking at subordination to the British Crown. The British Empire simply did not matter very much to the Irish. The conflict, in essence, was between Britain and Ireland, not Ireland and imperialism.

The positive arguments for Irish home rule repeated over many years, as the unionists had rightly insisted when spurning the benevolent bromides of Gladstonian Liberalism, were all in political logic "arguments in favour of Irish independence." ${ }_{68}$ The limitations on Irish sovereignty imposed by the home-rule policy were, for most nationalist electors, nothing more than a pragmatic recognition of the power of British or unionist obduracy. They were never seen as intrinsically valuable embellishments of self-determination. Few seriously doubted that home rule was intended by its Irish champions to evolve toward actual Irish sovereignty. In truth, pre-I9I4 advanced nationalists and home rulers "were looking for virtually the same goals," writes Conor Mulvagh, "the line of demarcation . . . rested on the question of tactics." ${ }^{99}$ The quotation chosen for inscription in gold on Dublin's Parnell monument, finally erected in I9IO, spoke volumes: "No man has the right to fix the boundary to the march

66. Bernard Porter's argument in The Absent-Minded Imperialists: What the British Really Thought about Empire (Oxford: Oxford University Press, 2004), while controversial, is no imperial apologia.

67. John Kendle, Ireland and the Federal Solution:The Debate over the United Kingdom, I870-I92I (Kingston and Montreal: McGill-Queen's University Press, I989), I38.

68. A. V. Dicey, England's Case against Home Rule (1886; Richmond, UK: Richmond Publishing, I973), I26-27.

69. Conor Mulvagh, The Irish Parliamentary Party at Westminster, 1900-18 (Manchester: Manchester University Press, 2016), 270. 
of a nation. . . We have never attempted to fix the ne plus ultra to the progress of Ireland's nationhood, and we never shall." ${ }^{70}$ Certainly unionists were sufficiently cognizant of the implication. ${ }^{71}$

Given the balance of forces, home rule seemed far more workable than immediate separatism up to I9I4. The attraction of home rule as a policy was that it seemed moderate enough to draw Britain into conceding and unionists into acquiescing without surrendering the ultimate aspiration for sovereign-Irish nationhood. But every unionist was well aware of the formal disjuncture between popularnationalist conviction and the diplomatic restraint of parliamentary leaders. As Michael Wheatley has found, "a clear strain of Anglophobia lay not even below the surface of nationalist thought: rather it was in the open and regularly expressed by politicians, clerics and newspapers." used too freely tends to caricature opposition to coercive British rule as pathological, the verbal militancy of constitutional nationalism is here accurately identified. ${ }^{73} \mathrm{John}$ Dillon in particular, as leader of the IPP's militant tendency, cleaved to the separatist tradition.

"Advanced nationalists" were at ease with home rule so long as it could be recognized as a means toward the end of accelerating the drive to Irish independence. Up until I9I4, this was more or less the case. "Arthur Griffith was not the man to stand in Redmond's way," Carlton Younger writes. "His own convictions were unchanged but he was ready to accept a home rule measure as a stepping-stone to a free and independent Ireland." ${ }^{\prime 4}$ James Connolly and Jim Larkin worked to establish an Irish Labour Party that could contest elections for the home-rule parliament. Patrick Pearse combined fiery language and ambitions- "I am the most dangerous revolutionary

70. For Parnell's speech clearly identifying, for those willing to hear, home rule as transitional to separation, see Charles Stuart Parnell at Cork City, 2I Jan. I885, in Alan O'Day and John Stevenson, eds., Irish Historical Documents since I80o (Dublin: Gill and Macmillan, I992), I05.

71. "The Unionist Case-Address by Lord Londonderry," Dublin Daily Express, 29 Nov. I9IO.

72. Michael Wheatley, Nationalism and the Irish Party: Provincial Ireland, 1910-1919 (Oxford: Oxford University Press, 2005), 94.

73. This is not to say that Anglophobia did not exist. Anna Parnell's Tale of a Great Sham (1907) is a hair-raising example. Notably, it could not find a publisher.

74. Calton Younger, Arthur Griffith (Dublin: Gill and Macmillan, I98I), 39. 
of the whole lot of them!"- -with public speaking in favor of home rule. ${ }^{75}$ For their part, at least in unguarded movements, constitutionalist nationalists luxuriated in thoughts of faithless Albion provoking a righteous tactical switchback. Henry Manson in July I9I4 gleefully warned that "like a mighty devastating torrent, the Irish Volunteers will sweep over Ireland [if betrayed by the English], and it will be well for England if they demand no more than home rule (loud and continuous applause)."76

The constitutionalist movement had been dedicated to establishing a national government toward which political parties native in Ireland could effectively orientate. It had generally been assumed by "advanced nationalists," and indeed by Redmond himself, that the IPP would continue to dominate after home rule was won, but not indefinitely: perhaps for two election cycles. As Horace Plunkett put it, "It is a commonplace of Irish politics that men are sent to Westminster for the sole purpose of getting home rule, and that a wholly different class of men would be sent to an Irish Parliament to work home rule." ${ }^{77}$ Advanced nationalists, the militant tendency of constitutionalism, expected to be these men, and they waited in the wings of home rule.

Constitutional nationalism and separatism were divided less by principle than considerations of political expediency. As P. S. O'Hegarty put it, "practically any generation of Irish men are liable to be drawn to a separatist movement if the separatists should develop a sufficiently attractive and workable policy." ${ }^{\prime 7}$ The balance of expedi-

75. Ruth Dudley Edwards, Patrick Pearse: The Triumph of Failure (1977; London: Gollancz, I990), I54-55. See also remarks by Desmond Ryan cited in Sean Edmonds, The Gun, the Law, and the Irish People (Tralee: Anvil Books, 1971), 42-43.

76. Michael Wheatley, Nationalism and the Irish Party: Provincial Ireland, I9IO-I9I9 (Oxford: Oxford University Press, 2005), 94.

77. Joseph Finnan, fohn Redmond and Irish Unity (Syracuse, NY: Syracuse University Press, 2004), I24. See also Paul Bew, Ideology and the Irish Question: Ulster Unionism and Irish Nationalism, 1912-I9I6 (Oxford: Clarendon Press, 1994), 7-8. The home-rule leaders were feeling their age: "too old for the job" and "only a matter of time before ... off to the knacker's yard," as Stephen Gwynn wrote to John Redmond in I916. Colin Reid, The Lost Ireland of Stephen Groynn: Irish Constitutional Nationalism and Cultural Politics, I864-I950 (Manchester: Manchester University Press, 20II), I37.

78. P. S. O'Hegarty, Sinn Féin: An Illumination (Dublin: Maunsel, I9I9), I3, quoted in M. J. Kelly, The Fenian Ideal and Irish Nationalism, I882-I9I6 (Woodbridge: Boydell and Brewer, 2006), 192. Cf. “. . . the Fenian spirit is ever present in Ire- 
ency changed in I9I4. To the horror of advanced nationalists, Redmond abandoned ambiguity. ${ }^{79} \mathrm{He}$ found himself constrained by the conjuncture to define home rule in immediate, practical terms as an imperial project, requiring Irish participation in a British war. On the outbreak of war, The O'Rahilly, an organizer of the Irish Volunteers, concocted plans to seize Dublin Castle, proclaim the home-rule government already enacted by Westminster, and to announce that the Irish Volunteers were now taking over the defense of Ireland. ${ }^{80}$ This scheme came to naught, but it was indicative of the separatist dynamic of home rule in Irish circumstances. Redmond's Woodenbridge Speech committing Irish resources to Britain's expeditionary force seemed to foreclose this dynamic. For understandable reasons Redmond treated home rule as a "final settlement" in I9I4. Sinn Féin never let him forget it. ${ }^{81}$

Britain made much of the rights of small nations over which the Central Powers ran roughshod, and naturally the home-ruler leaders, with an eye to Irish claims, echoed these sentiments. At the outset of the war, very many nationalists supported the call to arms as a vindication of the principle of national self-determination. Advanced nationalists were horrified at the idea that mere home rule, still less the promise of it, could be taken as warrant for a declaration of Irish belligerency, the ultimate act of sovereignty. But they broadly concurred with the widespread view of the war as inter-national, rather than inter-imperialist in the radical-socialist sense. The plans eventuating in I916 were drawn up with this understanding. Before hostilities ceased the separatists decided as early as September I9I4 that radical nationalists in Ireland must "declare war on England and,

land, and needs at any time but a little organisation to make it burst into renewed activity. . . . Disaffected we have been, disaffected we are, and disaffected we shall remain, till the English let go their grip of us." John O'Leary, Recollections of Fenians and Fenianism, 2 vols. (London: Downey, I896), 2:10.

79. Richard Dawson, Red Terror and Green: The Sinn-Féin-Bolshevist Movement (1920; London: New English Library, 1972), 98-99.

80. Aodogán O'Rahilly, Winding the Clock: O'Rahilly and the I9I6 Rising (Dublin: Lilliput Press, I99I), I50-5I.

8I. Nicholas Mansergh, Britain and Ireland (London: Longmans, Green, and Co., I942), 60. Note: "The man who accepts . . . as a 'final settlement' anything less . . . than separation . . . will be repudiated by the new generation." Pearse, "Ghosts" (I9I5), in Padraic Pearse, The Coming Revolution:The Political Writings and Speeches of Patrick (Cork: Mercier Press, 2012), I83. My emphasis. 
when the conference was held to settle the terms of peace, ... claim to be represented as a belligerent nation." ${ }^{82}$ The I9I6 rising duly took place. The rebels may have been foolhardy, many thought, but they were belligerents and as such lawful combatants. The shock of the I9I6 executions for much of Irish nationalist opinion derived from Britain highhandedly treating captured soldiers as traitors to be executed hors de combat rather than protected as prisoners of war. ${ }^{83}$

The Rising accelerated disillusion with the constitutionalist strategy. Even before Easter I9I6 it was increasingly clear that the price of home rule's constraints had become too high, as it now meant connection to Britain's world war, and its putative advantages diminished as it became obvious that Ulster unionists would not accept, nor would a British government enforce, a united Ireland home rule. The maximal separation of nationalist Ireland from entanglement with the United Kingdom, in a telescoped timeframe, became the new realism. By its propaganda against the Central Powers Britain had itself shifted the Overton window of the politically thinkable. "If Ireland's demands today are more far-reaching than they were a generation ago," wrote James Winder Good, "this is simply because she takes her stand on English declarations of the fundamental rights of small peoples held against their will in the grip of a stronger neighbour." ${ }^{84}$

A dividing point of principle did emerge when Sinn Féin in I9I7 adopted the goal of a republic. This was somewhat accidental-as with the French Third Republic, it was the ideal which at the time divided least - and was carefully framed in conditional rather than injunctional language. The real drive was toward Irish sovereignty. The relationship to the British state would be pragmatically organized once this had been accepted. "Independence first, inter-dependence afterwards," as Harry Boland put it. ${ }^{85}$

Even as the rise of Sinn Féin from I9I6 overpowered the IPP the

82. Sean T. O'Kelly, recalling a secret conference of separatists held on 9 September I9I4. See Dorothy Macardle, The Irish Republic (1937; London: Transworld Publishers, I968), II6.

83. George Bernard Shaw famously made this point at the time in a letter to the English press. It was resonant. See, for example, Ernie O'Malley, On Another Man's Wound (1936; Dublin: Anvil Books, 1990), 38-39.

84. James Winder Good, Irish Unionism (Dublin: The Talbot Press, I920), 187.

85. David Fitzpatrick, Harry Boland's Irish Revolution (Cork: Cork University Press, 2003), II3. 
divide between the parties was recognized as primarily tactical rather than principled. The I9I8 election, as republican veteran Marie Comerford noted, was a changing of the guard, not an ideological rupture. "The result of the election in Ireland was what elections had always been about since I 885 on-[and Ireland's representation] was held by nationalists." ${ }^{86}$ The difference was now that this nationalism, the profound substratum, had passed to the separatist vanguard, and they took this mandate to declare an independent Ireland.

The retreating constitutionalists attempted a red scare. In the East Clare by-election of July I9I7 the IPP predicted "red ruin and revolution" if Sinn Féin won. ${ }^{87}$ But in the 1918 election Sinn Féin successfully claimed Parnell as one of their own and welcomed Michael Davitt's children as campaigners for the party ${ }^{88}$ IPP objection was not so much to the end envisaged by Sinn Féin as to the viability and the cost of the proposed road. Primarily the IPP stressed that nationalists needed representation at Westminster to counter unionist influence and to twist the tail of the imperial lion. One Cork candidate, Richard O'Sullivan, even told an audience that constitutional nationalist MPs "would go to Parliament to demand the rights of Ireland, and if they were denied them there would be war." ${ }^{89}$ In their last attempts to retain influence, constitutional nationalists came out in favor of dominion status for Ireland, a settlement just short of independence. But this simply illustrated the shifting balance of forces as nationalist Ireland saw it. When Michael Collins retorted that "the same effort which would get us Dominion home rule would get us a republic," many agreed. ${ }^{90}$

As Martin Mansergh observes, there was no real class or ethnic difference between the IPP and advanced nationalists: "In truth the difference between the rival parties was temperamental. It was in this

86. Kenneth Griffith and Timothy E. O'Grady, Curious fourney: An Oral History of Ireland's Unfinished Revolution (London: Hutchinson, I982), I22.

87. M. J. Curran WS 687 (BMH, MA), 2 I4.

88. Patrick Maume, The Long Gestation: Irish Nationalist Life, I89I-I9I8 (Dublin: Gill and Macmillan, I999), 2 I2.

89. John Borgonovo, The Dynamics of War and Revolution: Cork City, I9I6-I9I8 (Cork: Cork University Press, 2013), 224.

90. Michael Collins interview in Freeman's fournal, 22 April 1922, reprinted in Arthur Mitchell and Pádraig Ó Snodaigh, eds., Irish Political Documents, 1916-1949 (Dublin: Irish Academic Press, 1985), 103. 
respect the difference between the Feuillants and the Jacobins in the French Revolution." ${ }^{\prime 1}$ Much of the early running of Sinn Féin in towns and villages was undertaken by former IPP adherents, such as United Irish League officials and local councilors. Thereafter, it developed as a generational divide. By the end of I9I8, however, even the Royal Irish Constabulary was convinced that Sinn Féin had the support of the great majority of all ages. ${ }^{92}$

Roy Foster has acutely delineated the intimate social world of that "revolutionary generation" of urban bourgeois-bohemians who threw themselves into the psychodrama of the I9I6 Rising. These assorted activists comprised a subculture rather than an overt opposition to mainstream nationalism before 19I4, and after I9I6 they became a fringe to the leviathan of Irish nationalism turned strategically separatist. Those survivors who emerged as republican leaders from the wreckage of the I9I6 Rising had often been only rather loosely attached to the hermetically entwined inner core of prewar radicalism. Michael Collins in I9I7 crisply repudiated the verbosity of the pre-I9r6 politico-litterateurs as past its sell-by date. ${ }^{93}$ Connolly's daughter learnt from De Valera that he "had never read anything of my father's, and had no idea what my father was like." ${ }^{94}$ As Foster writes, a "quiet revolution" in the minds of the young middles classes from the I890s onwards had expanded the repertoire of political language, but the militants of the Anglo-Irish War and Civil War were people of a quite different stamp. Typically, they were psychologically formed not by the political avant-garde but by long-standing community commitments to Irish independence and rejection of the moral authority of British law. ${ }^{95}$ IRA activity would be most effective

9I. Nicholas Mansergh, The Irish Question, I840-I92I (1965; Toronto: University of Toronto Press, I975), 249.

92. David Fitzpatrick, "The Geography of Irish nationalism, 1910-1921," in $\mathrm{Na}$ tionalism and Popular Protest in Ireland, ed. C.H.E. Philpin (Cambridge: Cambridge University Press, I987), 4I6-I8.

93. See Collins's one-sentence speech over the grave of Thomas Ashe. Robert Lynch, Revolutionary Ireland, 1912-25 (London: Bloomsbury Academic, 2015), 55.

94. Nora Connolly O'Brien, We Shall Rise Again (London: Mosquito Press, I98I), II.

95. Foster, Vivid Faces, 321. For the strong consciousness of the agrarian agitation and Moonlighter irregular warfare of the preceding generation, see Jeremiah Murphy, When Youth Was Mine: A Memoir of Kerry, 1902-1925 (Dublin: Mentor Press, I998), 25-30. 
where an engrained record of plebeian militancy was given shape by a leadership cadre drawn from the well-established middle ranks of rural society. ${ }^{96}$ This was less a radicalization than a retooling of traditional nationalism.

\section{Coercion to Create Constituencies}

Revolutionary and counterrevolutionary cadres typically use psychological and physical pressure to force those neutral in a confrontation - often a substantial minority and sometimes the majorityto choose sides. ${ }^{97}$ Little such coercion was required in Ireland. The constituencies already existed. The nationalist writer Benedict Kiely only admitted an "Irish revolution" as strictly sui generis: violence had not been employed to build any revolutionary constituency: "The Irish revolution [began] . . in an orderly meeting in a public building of the elected representatives of the people. The measures of physical force that were eventually resorted to were not a primary part of the revolution, which was something that the Irish people would have been very glad to do without." 98 The Crown authorities, admittedly, ascribed Sinn Féin's sweeping success in the I9I 8 general election to intimidation. ${ }^{99}$ Intimidation of a fairly quotidian type there certainly was (though not only from republicans, as police tried to repress manifestations of subversive disloyalty). ${ }^{100}$ On balance, however, David Fitzpatrick finds a majoritarian conformism rather than minority coercion. There was a "widespread

96. Tom Garvin, The Evolution of Irish Nationalist Politics (Dublin: Gill and Macmillan, I98I), I23-24.

97. See Alan Taylor, American Revolutions: A Continental History, I750-I804 (New York: W. W. Norton, 2016).

98. Benedict Kiely, Counties of Contention: A Study of the Origins and Implications of the Partition of Ireland (Cork: Mercier Press, 1945), I23.

99. Thomas R. Mocktaidis, British Counterinsurgency, 1919-60 (Houndsmill, UK: Palgrave Macmillan, I990), 65.

IOO. Intimidation was hardly unprecedented. Indeed, one form at least was suppressed by the rise of republicanism: "The country which had been shackled into silence by the terrorist methods of the [constitutional-nationalist] Board of Erin (which made the right of free meeting impossible by the use of their batons, bludgeons, and revolvers) was emancipated by the Dublin rising." See D. D. Sheehan, Ireland since Parnell (London: D. O’Connor, I92 I), 297. 
determination by ordinary Irish people to submit themselves voluntarily to a common discipline and to avoid a public display of conflict over political aims." ${ }^{101}$

The campaign of the IRA has been identified with "revolutionary warfare." For Francis Costello, IRA operations were "revolutionary" because they prefigured guerrilla struggle in the Guevarist mould. ${ }^{102}$ This is to confuse military tactics with political strategy, however. Revolutionary guerrilla warfare focused on capturing and controlling popular constituencies. This was always stressed as a priority. "Care must be taken to prevent the 'army line' . . from overriding the party line," wrote Josip Tito in I943 ${ }^{103}$ Ho Chi Minh advised his guerrilla units that "greater importance should be attached to the political side than to the military side." ${ }^{104}$ The IRA, however, did not function in this politico-military manner. Its armed campaign postdated the adherence of nationalist Ireland to Sinn Féin. IRA intimidation against the civilian population thereafter was used primarily to cut the police off from the "once prolific sources of talk-supply," as an IRA officer put it, of pub, shop, and street-corner gossip. ${ }^{105} \mathrm{It}$ was military and strategic, not ideological and political. The guerrilla campaign was not formulated but evolved out of the military exigencies of the IRA contest with Crown forces. ${ }^{106}$ As IRA commander Florence O'Donoghue recalled,

The guerrilla idea had come to be accepted; to which we owed the fact that the initiative was firmly in our hands. But that was a situation which could easily have been lost. ... Therefore, the tactics to be employed had to combine the elements of speed, surprise, and success. . . If evasion was essential to survival, evasion was the correct policy. The columns had to be kept in the field. . . L Local initiative had to be such that every unforeseen opportunity was snapped up on the instant; that there was no time and no area in which the enemy

IOI. Fitzpatrick, "Geography of Irish Nationalism," 4I4.

102. Francis Costello, The Irish Revolution and Its Aftermath, 1916-1923: Years of Revolt (Dublin: Irish Academic Press, 2003), 39.

I03. Josip Broz Tito, I6 Jan. I943, in William J. Pomeroy, ed., Guerrilla Warfare and Marxism (London: Lawrence and Wishart, 1969), I53.

I04. Ho Chi Minh, "Instruction to Establish the Vietnam Propaganda Unit for

National Liberation," 1944, cited in Pomeroy, Guerrilla Warfare, I53.

I05. Garvin, Nationalist Revolutionaries, I5I.

Io6. Sean Moylan, WS 838 (BMH, MA). 
would not feel that threat of potential damage so damaging to his nerves and morale. ${ }^{107}$

Guerrilla warfare was shaped by contact with the enemy much more than it was fashioned for the control and mobilization of the civilian population.

Robert Gerwarth has argued that the contestation of revolution and counterrevolution in central and eastern Europe terrifyingly blurred "the lines between friends and foes, combatants and civilians." 108 Ireland resembled this "arc of violence" as a spring to rivulet to a river. ${ }^{109}$ The death toll in the war of independence was astonishingly small. Of the 2,344 fatalities, most were uniformed members of Crown forces. Atrocity was never a standard modus operandi. Even in northeast Ulster intercivilian violence was strictly limited because, as Tim Wilson's excellent comparative study has shown, the political constituencies of nationalist and unionist were markedly rigid, being predefined by exclusive religious affiliation. There was little violence directed against neutrals or waverers, to force them to take sides, because such a floating vote on the constitution barely existed. ${ }^{110}$ Political constituencies did not need to be created. They were a given.

\section{Purging of the State Apparatus}

Revolutions typically see a substantial repopulation of the state apparatus, a disruptive process that significantly accounts for revolutionary trauma. ${ }^{111}$ There was little of this in Ireland because "the greening of Dublin Castle" had long been on track before I9I4. In I892, of fortyeight top positions forty-five were held by unionists. By I9I4 twenty-

107. Florence O'Donoghue, An Consantóir, 1946, in James Carty, ed., Ireland from the Great Famine to the Treaty of I921: A Documentary Record (Dublin: Fallon, I95I), 220.

I08. Robert Gerwarth, The Vanquished: Why the First World War Failed to End, I9I71923 (London: Allen Lane, 2016), I3.

I09. Constantine Fitzgibbon, Out of the Lion's Paw: Ireland Wins Her Freedom (London: Macdonald, I969), I02-3.

I Io. T. K. Wilson, Frontiers ofViolence: Conflict and Identity in Ulster and Upper Silesia, 1918-1922 (Oxford: Oxford University Press, 20I0), 20I-I I.

III. Jeff Goodwin, "State-Centered Approaches to Social Revolutions," in Theorizing Revolutions, ed. John Furan (London: Routledge, 1997). 
two of these positions were held by nationalists. The change was even greater further down the ranks. ${ }^{112}$ Protestants, of course, were disproportionately recruited, and those Catholics who were most favored came from families untypically loyal to the Crown. ${ }^{113}$ But further down the civil-service chain even militant nationalists were filtering into the ranks. "For some reason I am unable to fathom," complained Matthew Nathan, the undersecretary for Ireland, in I9I4, "a large proportion of people treasonable to England (patriotic to Ireland, they would put it) are to be found in the lower ranks of the government service." 114 From I9I6 the counter-colonization of the administration in Ireland only accelerated. "Home rule had proved an impossibility after the rising," Eunan O'Halpin writes, "the authorities hit instead on a form of "Rome rule," seeking to placate nationalist Ireland by putting Catholics in charge of the state apparatus." 115

Sinn Féin was thus "an inheritor party." The 1923 review of the civil service, a senior civil servant assured the minister, "will not necessitate very much time or enquiry." As Joe Lee drily remarks, "there can hardly be a blander commentary on the administrative implication of the Irish 'revolution." "116 Though there was a certain purging of the upper layers of the civil service, and more voluntary retirement, the 1936 reflection by Joseph Brennan, a senior civil servant, seems justified: "Under changed masters the main tasks of administration continued to be performed by the same staffs on the same general line." ${ }^{117}$ Ireland's state administration apparatus was smoothly maintained without rupture.

II2. Lawrence W. MacBride, The Greening of Dublin Castle: The Transformation of Bureaucratic and Fudicial Personnel in Ireland, I892-I922 (Washington, DC: Catholic University of America Press, I99I).

I13. Fergus Campbell, The Irish Establishment, I879-I9I4 (Oxford: Oxford University Press, 2009), 94-95.

II4. Leon Ó Broin, Dublin Castle and the I9I6 Rising (London: Sidgwick and Jackson, 1970), 33.

I I5. Eunan O'Halpin, The Decline of the Union: British Government in Ireland, I892I920 (Dublin: Gill and Macmillan, I987), I26.

II6. J. J. Lee, Ireland, 1912-1985: Politics and Society (Cambridge: Cambridge University Press, 1989), I06.

I17. Martin Maguire, The Civil Service and the Revolution in Ireland, 1912-1938: Shaking the Blood-Stained Hand of Michael Collins (Manchester: Manchester University Press, 2008), I, 227. 


\section{Significant Transformation in the Mode of Production, or at Least Property Allocation.}

Revolutions are often motivated by a desire to redistribute the allocation of productive property, and very occasionally, they succeed in so doing. ${ }^{118}$ Property ownership in Ireland certainly underwent profound change, but it was not the I9I2-23 "revolution" that established a property-owning democracy in Ireland. ${ }^{119}$ This had already come into existence principally as a result of the Land War (though it did require the end of British rule over all of Ireland to secure the sovereignty of that democracy). Fergus Campbell has shown that there were land seizures in the west of Ireland in 1920, but these were to considerable extent a cleaning-up operation in the aftermath of the Wyndham Land Act that sped the liquidation of landlordism and the establishment of peasant proprietorship. ${ }^{120}$ And while there was a formidable upsurge in wage-labor militancy from about I917, in particular in a semi-syndicalist "wages movement," there was no dynamic in the national struggle tending toward a dispossession of the bourgeoisie to match that of the landlords. As Michael Hopkinson notes, "the Irish revolution was not to be concerned with the redistribution of wealth." 121

There was, in Sinn Féin as well as Labour circles, some interest in promoting a "cooperative commonwealth" to cut out the "gombeen man" who stood between the direct producer and his market. The

II8. Tim McDaniel, Autocracy, Modernization, and Revolution in Russia and Iran (Princeton: Princeton University Press, I99I).

I I9. Diarmaid Ferriter implies that the "revolution" saw a new "hierarchy of benefit" benefiting publicans and shopkeepers. It is unlikely that publicans and shopkeepers were much more powerful in the new Ireland, which had on both sides of the border developmental states favoring large capital, than they had been since at least the I880s, when they provided the much of the cadre of the Land League. Along with larger farmers, they, rather than the landlords, were the principal beneficiaries of increases in land values since the Famine. Ferriter, A Nation and Not a Rabble: The Irish Revolution, 1913-23 (London: Profile Books, 2015), 4.

I20. Fergus Campbell, "Land and Revolution Revisited," in Land Questions in Modern Ireland, ed. Fergus Campbell and Tony Varley (Manchester: Manchester University Press, 2013), I5I. See also Fergus Campbell, Land and Revolution: Nationalist Politics in the West of Ireland I89I-I92I (Oxford: Oxford University Press, 2005), chapter 6.

I2I. Michael Hopkinson, The Irish War of Independence (Montreal: McGillQueen's University Press, 2002), 20. 
cooperative commonwealth, though an idea that deserves serious consideration, never looked like coming into existence. The national struggle took priority even for such an enthusiast for practical cooperativism as Paddy "the Cope." "One enemy at a time," he retorted to English unionists who taunted him on his nationalist alliance with exploiting merchants: "Of the two we have, we consider the English by far the worse. Whenever the gombeen man is fighting the English, we are with him in that fight, but as soon as we are rid of you, we will tackle him, and believe me, he will not last seven years, don't mind seven hundred." ${ }^{122}$ As it turned out, the gombeen man had little to fear. The national movement largely adopted a mythopoeia of Irish classlessness. All social strata in Ireland, wrote Daniel Corkery later, including "our hierarchy, priesthood, parliament, professors, doctors, lawyers, civil servants, merchants, manufacturers, not to say workers," had arisen from a rural proletariat, "almost sheer from the soil." "23 Unsurprisingly, ideologies of class conflict found it difficult to gain traction in a nationalist tradition that placed only landlords on one side, all other classes on the other. Sinn Féin's approval of cooperative production was generally limited to the political aim of promoting "national" enterprises preferentially employing nationalists. ${ }^{124}$ Once Irish sovereignty was established, and concerns regarding antinational discrimination faded outside Northern Ireland, the existing social structure of Ireland was considered to be adequately racy of the soil. Social revolution never looked a possibility.

\section{The Establishment of a New Dominant Ideology.}

Revolutions are often held to establish new and enduring norms, marking a caesura in the political and social language of society. ${ }^{125}$ This Irish "revolution," however, failed to produce truly noteworthy

I22. Patrick Gallagher, "Paddy the Cope," My Story (I947; Tralee: Kerryman, I979), I39.

123. Daniel Corkery, The Fortunes of the Irish Language (Cork: Mercier Press, I954), I24.

I24. Moirin Chavasse, Terence MacSwiney (Dublin: Clonmore and Reynolds, I961), 109.

I25. Lynn Hunt, Politics, Culture, and Class in the French Revolution (Berkeley: University of California Press, 1984). 
political thinkers. ${ }^{126}$ There was no marked shift in the political ideology or historical imagination of nationalist Ireland and unionist Ulster in the period 1912-23. ${ }^{127}$ State sanctioned republicanism was little more than a reordering of nationalist verities and hero-figures. While Ulster unionism became less "Irish" in self-perception, it did not, as many thought it might, develop into an Ulster nationalism.

The most striking innovation in Irish nationalism was its cultural Gaelicism. But this had made most of its advances before I9I4: a mass-movement lobbying of local authorities, promotion of reading and writing Irish in schools, competence in Irish a prerequisite for entry to the new National University and an increasing number of local authority jobs, an Irish-language literary milieu, a stream of Irish-language publications, and Irish-language street-name plates in Dublin. ${ }^{128}$ The pivotal change had been the democratization and "nationalization" of local government in I898. Independence consolidated these promotions and probably slowed the decline of the language in its everyday transactional use. Otherwise, there were few fundamental advances to report.

Much has been made recently of the feminist charge of the "Irish revolution." But we must not overstate the case. Female suffrage was controversial before I9I4 largely because its exercise had been associated with those subordinate legislatures denied sovereign authority (states in Australia and the United States, Finland in the Tsarist Empire). Female suffrage had been part of the devolutionary Irish councils package proposed by the Liberal government in 1907 and rejected by Irish nationalists as insultingly inadequate. During the debate at Westminster on the I9I2 Home Rule Bill, Philip Snowden, for Labour, while admitting that "there has not been that widespread agitation for woman suffrage in Ireland that there has been in other

I26. Thomas Duddy, A History of Irish Political Thought (London: Routledge, 2002), 288. James Connolly was more significant as a historian than an original Marxist (or syndicalist) thinker. Ernie O'Malley wrote perhaps the most important book by a participant on the "revolution," On Another Man's Wound (I936), but it stands as literature rather than conceptual analysis.

I27. R. F. Foster, "History and the Irish Question." in R. F. Foster, Paddy and Mr Punch: Connections in Irish and English History (London: Penguin Books, I993), I4-I5.

I28. Liam Mac Mathúna, "The Gaelic League and the Changing Role of Literacy in Ireland," in The Irish Revival Reappraised, ed. Betsey Taylor FitzSimon and James H. Murphy (Dublin: Four Courts Press, 2004), 60-6I. 
parts of the United Kingdom," 129 argued that anti-suffrage MPs could hardly oppose women having the vote in this instance because it "would be perfectly consistent and proper that women should be enfranchised so far as a subordinate parliament is concerned, while denied the vote for the imperial parliament dealing with larger concerns." 130 Walter Long for the Unionists did in fact support the amendment, in the hope of wrecking the bill, though he opposed female suffrage for the imperial parliament.

Right through to I9I4 the position of home rule MPs was that an Irish Parliament should be conceded without female suffrage attached as a prerequisite, which would be a badge of constitutional inferiority (Carson's proposed unionist parliament for Ulster would welcome female electors precisely because unionists gloried in the supremacy of the "imperial parliament"). Most nationalists were not opposed to female suffrage sine die; they wanted an Irish parliament, once established, to legislate female suffrage (or not) on its own quasi-sovereign competence. ${ }^{131}$ This was an increasingly embarrassing piece of constitutional persnicketiness, rather representative of how its oblique approach to acquiring Irish sovereignty tied moderate nationalism up in knots. The leaders of the 1916 Rising handily cut this particular Gordian knot by declaring women enfranchised by the Irish republic, and there was no difficulty in welcoming female voters in the UK I9I8 general election that established Dáil Éireann. But all this was a secondary effect of the primary struggle to establish Irish sovereignty.

Women did play a significant role in the extraparliamentary sphere. Culture, education, and shopping were well-established as appropriately feminine spheres, and women were generally prominent in the cultural-nationalist language and home-industries movements before I9I4. ${ }^{132}$ State formation and defense were rather different matters

I29. Parliamentary Debates: Official Report (I9I2), cclxxi.

130. Parliamentary Debates: Official Report (I9I2), cclxxxii.

I3I. According to William Redmond in 1912, "The Irish people are certainly the people to settle this question for themselves." Parliamentary Debates: Official Report (I9I2), cclxxix. John Redmond in I9I4 asserted, "Ireland should decide for herself under home rule whether she desires women's suffrage or not." See Leah Levenson, With Wooden Sword: A Portrait of Francis Sheehy-Skeffington, Militant Pacifist (Boston, MA: Northeastern University Press, 1983), 158.

132. Senia Pašeta, Irish Nationalist Women, 1900-1918 (Cambridge: Cambridge University Press, 2013), I30. 
and the only active republican women's organization from early I9I9 at least was Cumann na mBan, a covertly organized auxiliary to the IRA "whose members tended to be thought of as camp-followers." Later feminists regretted that it never had the "independence and flow of creative ideas" that had characterized its predecessor, Inghinidhe na hÉireann. ${ }^{133}$

Feminists understandably celebrated the fact that the I9I6 Rising proclamation had been addressed to "Irishmen and Irishwomen," though this form of interpellation was not entirely new. ${ }^{134}$ But the I9I8 election returned only one woman, Contance Markievicz for Sinn Féin. "This is the measure of our boasted sex equality," the Irish Women's Franchise League noted glumly_ "reaction has not died out with the Irish Party." 135 In the period of the Anglo-Irish War, women were not infrequently victimized, but they were by no means on the front line. It is striking that only fifty women were imprisoned during the Anglo-Irish War, and their sentences were usually short. ${ }^{136}$ By the time the new state had consolidated, the tight limits on female authority were clear enough. Between 1922 andi972, women TDs comprised only three percent of the average Dáil, most of these being widows or other relatives of deceased members. Only seven women were elected to the Dáil in the period 1922-37. ${ }^{137}$ In terms of ideology, there was far more continuity than discontinuity between Ireland under Union and out from under it.

133. Elizabeth Coxhead, Daughters of Erin: Five Women of the Irish Renascence (London: Secker and Warburg, I965), 42. See also Ann Matthews, Renegades: Irish Republican Women, 1900-1922 (Cork: Cork Mercier Press, 2010), 240.

I34. The same mode of address was used in a handbill titled "Handbill Announcing Anniversary of the Siege of Limerick, Organised by J. McDonnell in London, I869," reproduced in Seán Daly, Ireland and the First International (Cork: Tower Books, I984), 5 I.

135. Rosemary Cullen Owens, "Votes for Women," in The Irish Women's History Reader, ed. Alan Hayes and Diane Urquhart (London: Routledge, 200I), 42.

136. Myrtle Hill, Women in Ireland: A Century of Change (Belfast: Blackstaff, 2003), $82-83$. There were about 4,000 Irish nationalists in prison by the time of the Truce in I92I.

I37. Maedhbh McNamara and Paschal Mooney, eds., Women in Parliament: Ireland, 19I8-2000 (Dublin: Wolfhound Press, 2000), I6. 


\section{"The Uprising"-A New Generation and a Small INTERNATIONAL WAR}

In the period I9I2 to I923 a new state was founded and violence was employed to assert and contest its claims. While it would be churlish to blankly deny any family resemblance to revolution, one is struck more forcefully by the lack of revolutionary dynamics. The first half of the period saw a generational shift in mainstream nationalist leadership, such as had quite frequently punctuated the nineteenth century: in the I820s when the O'Connellites pushed aside the Patriot gentry, in 1852 when the Sadlier and Keogh's "Irish Brigade" filled the vacuum left by exhausted O'Connellites, in I874 when home rulers succeeded liberal parliamentarians cut off from popular opinion, and in I880 when Parnellites overthrew the timid Buttites.

Rather than simply changing the guard at Westminster, however, Sinn Féin founded a state. Elected in 1918, Dáil Éireann saw itself not as a defiant revolutionary institution, but as the government of Ireland, de jure and de facto. "There is in Ireland at this moment only one lawful authority," De Valera told the Dáil in 1919, "and that authority is the elected government of the Irish republic." " 138 Terence Mac Swiney at his court-martial refused to recognize the crown's presumption of legal authority: "The position is this: I am lord mayor of the city and its chief magistrate, and I declare this court is illegal, and that all taking part in it are liable to arrest under the laws of the Irish republic." 139 The Dáil established or coopted a ramified state apparatus - courts, police, army, and local government - that reached its high-water mark in the summer of 1920 . "It was now seen by many, if not most, people as the de facto government of the country," writes Arthur Mitchell. ${ }^{140}$

The military arm of Irish sovereignty was the IRA. This was the case even before the Irish state took institutional form as Dáil Éireann in I9I8, for the Irish Volunteers were established in I9I4 as the "the

138. "The President's Statement to the Dáil, Io April 1919," in Irish Historical Documents, II72-1922, Edmund Curtis and R. B. McDowell (London: Melhuen, I943), 320.

I39. Quoted in Muriel MacSwiney, Letters to Angela Clifford (Belfast: Athol, 1996), 25 .

I40. Arthur Mitchell, Revolutionary Government in Ireland: Dáil Éireann, 1919-22 (Dublin: Gill and Macmillan, 1995), I54. 
nucleus of a permanent defence force, of a National Army." It was "an arm and a possession of the whole nation, the focus of its defence and the necessary guardian of its liberties both now and hereafter." ${ }^{141}$ De Valera, as president of Dáil Éireann, insisted that the IRA was a "regular state force," a "national army of defence" rather than the "praetorian guard" of a political party. ${ }^{142}$ This view of the IRA as the army of a state, engaged in international warfare with the British, was accepted by IRA volunteers. For Tom Barry, "the Irish volunteers were to be the army of the republic, with the moral and legal status of a lawfully-organised army of the democratic government." 143 British observers acknowledged the "military spirit" and discipline of the IRA. ${ }^{144}$ Charles Street, information officer for the British administration at Dublin Castle, was well aware that republicans were a constituted governmental authority: "It must be remembered from the outset that ... the various republican organisations considered themselves as the directing force of the de facto Irish republic, of which the government was Dáil Éireann, and the policy the conduct of war on the British Empire in general and the forces of the Crown in particular." 145

It is doubtful whether we can see this situation as revolutionary in the sense outlined by Charles Tilly and borrowed by Peter Hart. In truth, by I9I9 there was no contest for popular legitimacy between the Dáil and the British government. Nationalist Ireland accepted the Dáil and unionist Ireland accepted British sovereignty. Neither side struggled politically to debate the other, to force people to take sides, or to induce them shift allegiance from one to the other. This was a military contest between the governments of two states, one

I4I. "We Have the Men!" Dec. I9I3, in F. X. Martin, ed., The Irish Volunteers, 1913-1915: Recollections and Documents (Dublin: James Duffy, I963), II9.

I42. Charles Townshend, The Republic: The Fight for Irish Independence, 19I8-I923 (London: Allen Lane, 2013), 232.

I43. Tom Barry, Guerrilla Days in Ireland: A Personal Account of the Anglo-Irish War (1949; Boulder: CO: Roberts Rinehart, 1995), I2. This is all the more striking coming as it does from Barry, an inveterate militarist ever suspicious of mere politicians. Cf. Ewan Butler, Barry's Flying Column: The Story of the IRA's Cork No. 3 Brigade, I9I9-2I (London: Leo Cooper, I97I), 98.

I44. Contemporary comments by Lieutenant-General Sir H. Lawson and Lord French, quoted in Sean O'Callaghan, The Easter Lily: The Story of the IRA (London: Four Square Books, 1967), 34-35.

I45. "I.O.," The Administration of Ireland, 1920 (London: Phillip Allan, I92 I), I63. 
seeking to break the power of the other on the territory being fought over, as in any international war.

The position of the Catholic Church, on principle opposed to revolution, was indicative. The British Foreign Office worked "might and main" to convince the Vatican that the republican government was an attempt at "anarchical revolution promoted by irresponsible men whose main technique was murder." ${ }^{146}$ But the hierarchy refused to accept either British or Dáil pretensions to legitimate governmental power as valid. Archbishop Harty's 1920 Lenten pastoral is interesting in the manner in which it addressed the problem: "We are living under a government which has proved itself an abject failure... The remedy of the Irish upheaval is obvious, since freedom is the best solvent of political disorder." 147 Something similar, though milder, can be seen in the hierarchy's joint statement of January 1920. ${ }^{148}$ There was a kind of Hobbesian logic at work here, seeking to square a circle. Revolution against government is illegitimate, but in the absence of real government (which to qualify as such must at least offer peace, even if by repression) the faithful may legitimately seek to "reconstruct" it. Such reconstruction of order was always likely to be on the basis of recognition of Irish sovereignty. Thus did the hierarchy envisage regime change without revolution.

Britain slowly became aware that they were confronted not by "civil war" but by an international conflict. ${ }^{149}$ In May 1920 Sir Denis Henry, the attorney general of Ireland, told the House of Commons

I46. Patrick J. Doyle WS 807 (BMH, MA), 23.

I47. Dermot Keogh, TheVatican, the Bishops, and Irish Politics, 1919-39 (Cambridge: Cambridge University Press, I986), 39.

I48. For Northern Ireland specifically, the June 1922 pastoral issued by the bishops collectively complained of the lack of government for Catholics in Northern Ireland, thus permitting lack of compliance with authority.

I49. Mo Moulton has argued that we should see this period as a civil war within and even throughout the United Kingdom. See their Ireland and the Irish in Interwar England (Cambridge: Cambridge University Press, 20I4), I2 and passim. This is unpersuasive. Britain and Ireland overwhelmingly looked upon each other as distinct countries. Even settled Irish communities in Great Britain were seen as somewhat foreign. A Christian socialist Labour candidate in I92 I for the seat of Central Leeds recalled that its "inhabitants were rather exotic: Jews in the centre and Irish Catholics in the south of the division; only in the western end were there to be found normal Yorkshire workers, railwaymen or engineers." Henry H. Schloesser, fudgement Reserved: The Reminiscences of the Right Honourable Sir Henry Slesser (London: Hutchinson, I94I), 88. 
what was at stake in the ongoing assault on British power in Ireland: "It is not an attack on one party, it is not an attack on the coalition government, it is an attack on your nation. It is an attempt to drive your nation out of Ireland." 150 Just over a year later, in June I92 I, Lord Birkenhead conceded to the House of Lords that events in Ireland amounted to "a small war." ${ }^{151}$ It was a very public humiliation for Britain. As the left-Fabian Margaret Cole wrote in I949, "the Irish war was ended, of course, largely because the bulk of the English public were ashamed of what was being done in their name, and quite unprepared for the real war which would have been needed to reconquer Ireland.”152

There was revolutionary potential in these troubles, some of which emerged during the Civil War after the Treaty ended armed conflict with Britain. Clearly the fledging Irish state suffered a crisis as international pressure (from Britain) split its armed force, the IRA. There was no notable uptick in popular mobilization, but class conflict did accentuate. Social radicalization focused in the west of Ireland, where class tensions over land were strongest. There were shades of proletarianization of the urban popular constituency on the anti-Treaty side, matched by a vigorous rhetoric of anti-red social conservatism on the pro-Treaty side. ${ }^{153}$ Nationalists mutually radicalized and ideologically polarized. Both sides in the Civil War applied pressure to carve out popular constituencies, notably by intimidating the press and appealing to the anathemas of the Catholic Church. The state was restructured as pro-Treaty forces constituted the National Army with Britain's help and the anti-Treaty IRA targeted "big houses" as the nodal points of reactionary power that might, when combined with the formal limitations imposed by the Treaty, vitiate Irish sovereignty. ${ }^{154}$ There was no significant change to property alloca-

I50. A. D. MacDonnell, The Life of Sir Denis Henry: Catholic Unionist (Belfast: Ulster Historical Foundation, 2000), 6I.

I5 I. Kevin Matthews, Fatal Influence: The Impact of Ireland on British Politics, 19201925 (Dublin: University College Dublin, 2004), 33.

I52. Margaret Cole, Growing Up into Revolution (London: Longmans, Green, and Co., I949), 84 .

I53. Paul Bew, Ireland: The Politics of Enmity, I789-2006 (Oxford: Oxford University Press, 2007), 439-40.

I54. The "big house" had long been seen by nationalists as the material condensation of reaction. As an IRA veteran wrote, "the big house had a powerful denationalis- 
tion and-other than a certain Catholicization of public cultureno new norms established. Rather mild revolutionary and counterrevolutionary currents more or less canceled each other out.

Sinn Féin rapidly disaggregated into government-seeking umbrella parties. Cumann na nGaedheal and the "slightly constitutional" Fianna Fáil were not radically different from the parties we might have expected to see arise from nationalist forces in a home rule parliament. Both were intent on pushing the established structures toward maximally unfettered Irish sovereignty, though with differing calculations of appropriate speed. With unionist Ulster partitioned off, and Britain unable to bring military weight to bear in support of the letter of the Treaty, their success was only a matter of time. It was not so much that Ireland had undergone a profound revolution; more that Britain had lost a war.

ing effect on the people. From time to time it pauperised, demoralised and tried to anglicise them. The Castle [in Dublin] might be referred to as the great big house. It coordinated the activities of all the big houses around it, as well as demoralising its own vicinity." Micheál Ó Suilleabháin, Where Mountainy Men Have Sown: War and Peace in Rebel Cork in the Turbulent Years, 19I6-2I (Tralee: Anvil Books, 1965), 139. See also Gemma Clark, Everyday Violence in the Irish Civil War (Cambridge: Cambridge University Press, 2014), 67. 